\title{
In Vivo Human Carboxylesterase cDNA Gene Transfer to Activate the Prodrug CPT-11 for Local Treatment of Solid Tumors
}

\author{
Akira Kojima, Neil R. Hackett, Akihiko Ohwada, and Ronald G. Crystal \\ Division of Pulmonary and Critical Care Medicine, The New York Hospital-Cornell Medical Center, New York 10021
}

\begin{abstract}
To evaluate the concept that in vivo transfer of the human carboxylesterase gene will confer sensitivity of a solid tumor to the prodrug CPT-11 (irinotecan), we constructed an adenovirus vector (AdCMV.CE) carrying the human carboxylesterase gene driven by the cytomegalovirus (CMV) promoter, infected A549 human lung adenocarcinoma cells in vitro and in vivo, and evaluated cell growth over time. AdCMV.CE produced a functional carboxylesterase protein in A549 cells in vitro and in vivo as evidenced by ability of lysates from the infected cells to convert CPT-11 to its active metabolite SN-38. The AdCMV.CE vector effectively suppressed A549 cell growth in vitro in the presence of CPT-11. Cell mixing studies demonstrated that when as few as $10 \%$ of cells expressed the human carboxylesterase gene, there was bystander growth suppression in the presence of CPT-11. Consistent with these in vitro observations, when AdCMV.CE was directly injected into established subcutaneous A549 tumors in nude mice receiving CPT-11, there was $35 \%$ reduction in tumor size at day 27 compared to controls, and a $41 \%$ reduction at day $34(P<0.01$, both comparisons to controls). Similar observations were made with the cell line H157 and HeLa. These observations suggest that local gene transfer of the human carboxylesterase gene and concomitant local administration of CPT-11 may have potential as a strategy for control of the growth of solid tumors. (J. Clin. Invest. 1998. 101:1789-1796.) Key words: carboxylesterase • adenovirus • gene therapy • camptothecins • lung cancer
\end{abstract}

\section{Introduction}

Irinotecan; 7-ethyl-10-[4-(1-piperidino)-1-piperidino] carbonyloxy-camptothecin (CPT-11), ${ }^{1}$ a camptothecin analogue that functions as an inhibitor of mammalian DNA topoisomerase I, is a chemotherapeutic agent that is active against lung, cervi-

Address correspondence to Ronald G. Crystal, M.D., Division of Pulmonary and Critical Care Medicine, The New York Hospital-Cornell Medical Center, 520 East 70th Street, ST505, New York, NY 10021. Phone: 212-746-2258; FAX: 212-746-8383.

Received for publication 17 December 1996 and accepted in revised form 24 February 1998.

1. Abbreviations used in this paper: CE, carboxylesterase; CPT-11, 7-ethyl-10-[4-(1-piperidino)-1-piperidino] carbonyloxy-camptothecin; MTT, 3-[4,5-dimethylthizol-2-yl]-2,5-diphenyl tetrazolium bromide.

J. Clin. Invest.

(C) The American Society for Clinical Investigation, Inc. 0021-9738/98/04/1789/08 \$2.00

Volume 101, Number 8, April 1998, 1789-1796

http://www.jci.org cal, ovarian, and colorectal tumors, as well as leukemias and lymphomas (1-5). Structurally, CPT-11 is unique among the camptothecins because of the bulky piperidino side chain located at the C-10 position (6). This side chain can be cleaved enzymatically by carboxylesterase to SN-38 (7-ethyl-10-hydroxycamptothecin), that functions as a topoisomerase I inhibitor that is 1,000-fold more potent than CPT-11 (7). Since carboxylesterase (CE) activity is found in serum, liver, intestines, and other sites, CPT-11 is classified as a "prodrug", that is activated in vivo to the more potent $\mathrm{SN}-38$ (8). In contrast to CPT-11 which is soluble in aqueous solutions, $\mathrm{SN}-38$ is insoluble, and thus not useful as a chemotherapeutic agent, despite its potency (9). Although CPT-11 is now available as a chemotherapeutic agent for some indications, its usefulness is limited by dose-dependent toxicity, primarily diarrhea and granulocytopenia (10). In part, this may be due to the genetically determined variability of available carboxylesterase activity, resulting from individual to individual variation in the total amount of SN-38 generated for a given dose of CPT-11 (11).

Theoretically, one strategy to circumvent the toxicity of CPT-11 would be to transfer the carboxylesterase gene directly to the tumor, then administer the CPT-11 directly to the tumor, i.e., a regional chemotherapeutic strategy where the prodrug CPT-11 would be converted to the more active SN-38 within the tumor, consequently maximizing the exposure of the tumor cells to the active agent while limiting systemic concentrations of these drugs and thus the systemic toxicity associated with the conventional use of CPT-11. To evaluate this chemotherapeutic paradigm, we constructed a recombinant, replication deficient adenovirus vector coding for the human carboxylesterase cDNA and have used the combination of local delivery of this gene transfer vector and CPT-11 to suppress the growth of lung tumor cells.

\section{Methods}

Adenovirus vectors. Two Ad vectors were used in this study: AdCMV.CE (expressing the human carboxylesterase cDNA driven by the cytomegalovirus promoter/enhancer [CMV]) and AdCMV.Null (identical, but with no transgene) (12). To construct the AdCMV.CE vector, unique restriction sites were added to a fragment of $1.7-\mathrm{kb}$ human carboxylesterase cDNA (a gift of D.L. Kroetz, University of California, San Francisco, CA) (13) to facilitate subcloning into the KpnI and SpeI multiple cloning site of the Ad expression plasmid pCMV.SV2 ${ }^{+}$(14). After the sequencing for full length cDNA to insure fidelity, the resulting shuttle plasmid (pCMV.CE) was cotransfected into 293 cells with pJM17 plasmid containing the Ad type 5 genome by calcium phosphate precipitation (15-18). The recombinant AdCMV.CE vector was isolated from a single plaque, expanded in 293 cells, and purified by double cesium gradient ultracentrifugation, and dialysis (18). The titer of the purified Ad was determined using 293 cells as previously described (18).

Materials. The lung carcinoma cell lines A549, H157, SK-MES1, H292, Calu6, H82, H520, H345, the colorectal cancer cell line HT29, and the cervical cancer cell line HeLa were obtained from American Type Culture Collection (ATCC, Rockville, MD). The lung carcinoma cell line HS24 were provided by W. Ebert, Thraxklinikum 
Heidelberg-Rohrbach (Heidelberg, Germany). A549, SK-MES1 were grown in minimal essential media (GIBCO-BRL, Gaithersburg, MD) with $10 \%$ fetal bovine serum, $50 \mathrm{U} / \mathrm{ml}$ penicillin $\mathrm{G}$, and $50 \mu \mathrm{g} / \mathrm{ml}$ streptomycin. H157, H292, Calu6, H82, H520, H345, HS24, and Hela were grown in RPMI1640, and HT-29 were grown in McCoy's 5A with fetal bovine serum and antibiotics in same concentration. CPT-11 and SN38 were kindly provided by Yakult Honsha Co. Ltd. (Tokyo, Japan).

In vitro expression of the carboxylesterase $c D N A$. The expression of the carboxylesterase cDNA following in vitro transfer with the AdCMV.CE vector was evaluated at the mRNA and protein levels. To evaluate the expression of the AdCMV.CE vector at the mRNA level, A549 cells $\left(5 \times 10^{6}\right)$ were plated in a 15 -cm culture dish (Falcon, Franklin Lakes, NJ), and after $16 \mathrm{~h}$, the cells were infected with AdCMV.CE or AdCMV.Null (30 moi) in serum-free MEM. After $90 \mathrm{~min}$, the culture medium was replaced with fresh serum containing medium, and the cultures continued for $48 \mathrm{~h}$. Total RNA extracted from the cells was evaluated by Northern analysis $(10 \mu \mathrm{g} /$ lane) using hybridization with a ${ }^{32} \mathrm{P}$-labeled $1.7 \mathrm{~kb}$ full-length human carboxylesterase cDNA probe (19). As a control, the membrane was then stripped and probed with a ${ }^{32} \mathrm{P}$-labeled glyceraldehyde-3-phosphate (GAPDH) probe (20).

To demonstrate that a functional carboxylesterase enzyme was expressed in the A549 cells infected with the AdCMV.CE vector, the whole-cell extract was prepared by sonication and centrifugation $(14,000 \mathrm{rpm}, 30 \mathrm{~min})$. A reaction mixture was prepared in $200 \mu \mathrm{l} \mathrm{con-}$ taining $4 \mu \mathrm{l}$ of whole-cell extract, $1.6 \mathrm{mM} p$-nitrophenyl acetate and $100 \mathrm{mM}$ Tris- $\mathrm{HCl}, \mathrm{pH} 8.0$; the mixture was then incubated in a 96well plate at $23^{\circ} \mathrm{C}$. The optical density at $405 \mathrm{~nm}$ was measured continuously for $10 \mathrm{~min}$ to detect the metabolite of the carboxylesterase reaction ( $p$-nitrophenol) using a microplate reader (Model 450; BioRad, Hercules, CA) (21).

To evaluate the precursor/product relationship of CPT-11 and SN-38 after AdCMV.CE infection of A549 cells and the addition of CPT-11 to the cultures, A549 cells $\left(10^{7}\right)$ were infected with AdCMV.CE or AdCMV.Null (50 moi) and incubated in culture plates with medium containing $100 \mu \mathrm{M} \mathrm{CPT}-11$ at $37^{\circ} \mathrm{C}$ for $10,20,40,60$, and $120 \mathrm{~min}$. After two washings with ice cold PBS, pH 7.4 the cells were sonicated and centrifuged $(14,000 \mathrm{rpm}, 30 \mathrm{~min})$. The CPT-11 and $\mathrm{SN}-38$ content of the supernatant was quantified by a modification of the high performance liquid chromatography method of Barielo et al. (22) using a $\mathrm{C}_{18}$ reversed phase column ( $\mu$ Bondapak, $10 \mu \mathrm{m}$, $3.9 \times 300 \mathrm{~mm}$; Waters Associates, Milford, MA) preceded by a $\mathrm{C}_{18}$ Novapak guard column. Detection was monitored by a Waters 484 tunable absorbance detector (Waters Associates) at $370 \mathrm{~nm}$ wavelength. The mobile phase (flow rate $0.6 \mathrm{ml} / \mathrm{min}$ ) was acetonitrile- $0.1 \mathrm{M}$ potassium dihydrogen phosphate $(35: 65)$ containing $3 \mathrm{mM}$ sodium heptane sulphonate (pH 4.0). Camptothesin (Sigma Chemical Co., St. Louis, MO) was used as an internal standard.

Cytotoxicity. Cytotoxicity of the infected cells following infection with Ad vector \pm CPT-11 was measured using a 3-[4,5-dimethylthizol2-yl]-2,5-diphenyl tetrazolium bromide (MTT) assay (23). Cell lines $\left(4 \times 10^{3}\right)$ infected with AdCMV.CE or AdCMV.Null (50 moi) were seeded and incubated with CPT-11 (0.1 to $100 \mu \mathrm{g} / \mathrm{ml})$ for $72 \mathrm{~h}$. After $4 \mathrm{~h}$ of incubation with MTT substrate $(10 \mathrm{mg} / \mathrm{ml})$, the media was removed and DMSO was added. The optical density at $540 \mathrm{~nm}$ was measured using a microplate reader. The cytotoxicity of each cell line was evaluated as: $\Delta \mathrm{IC}_{50}=\left(50 \%\right.$ inhibitory concentration $\left[\mathrm{IC}_{50}\right]$ value after infection with AdCMV.Null [moi 50] $) /\left(\mathrm{IC}_{50}\right.$ value after infection with AdCMV.CE [moi 50]).

Bystander effect. Two approaches were used to examine whether AdCMV.CE-mediated transfer of the carboxylesterase cDNA combined with exposure to CPT-11 resulted in a "bystander effect," where cytotoxicity was observed in cells in addition to those infected with the AdCMV.CE vector. First, A549 cells were infected in suspension with AdCMV.CE or AdCMV.Null (50 moi) or left uninfected, then allowed to adhere. After $72 \mathrm{~h}$, cells were resuspended in media containing CPT-11 $(10 \mu \mathrm{g} / \mathrm{ml})$ and mixtures $(0-100 \%)$ of infected cells were plated in a 96-well plate, giving a total of $4 \times 10^{3}$ cells/well. These cell mixtures were maintained in culture for $72 \mathrm{~h}$, and the viable cell number was then assessed using a MTT assay (23). Second, to determine whether this bystander effect was dependent on cell-to-cell contact or whether mediated by active metabolites liberated from cells expressing the carboxylesterase gene, A549 cells $\left(10^{6}\right.$ cells/dish) were infected in suspension with AdCMV.CE or AdCMV.Null (50 moi), or no virus, then after $90 \mathrm{~min}$, the culture medium was replaced with fresh serum containing medium, and the culture contained for $24 \mathrm{~h}$. The media was aspirated and the cells washed with PBS to remove any remaining free virus. The media was replaced with media containing $10 \mu \mathrm{g} / \mathrm{ml} \mathrm{CPT-11}$ and incubated for $24 \mathrm{~h}$. This media was collected and serial dilutions were made with fresh serum containing media, transferred to triplicate monolayers of naive A549 cells $\left(4 \times 10^{3}\right.$ cells/well) in a 96-well plate, and incubated $(72 \mathrm{~h}$, $37^{\circ} \mathrm{C}$ ). Viable cell number of the A549 cells then was assessed using the MTT assay.

In vivo evaluation of AdCMV.CE. To demonstrate that local administration of AdCMV.CE vector resulted in the expression of carboxylesterase within the tumor, A549 cells $\left(8 \times 10^{6}\right)$ were injected subcutaneously in the flanks of athymic Balb/c nu/nu mice (Charles River Laboratories, Wilmington, MA). Established tumors (4-10 $\left.\mathrm{mm}^{2}\right)$ were injected with AdCMV.CE or AdCMV.Null ( $\left.10^{9} \mathrm{pfu}\right)$ using a 28-gauge needle directed to three sites. After $5 \mathrm{~d}$, a total of $100 \mu \mathrm{l}$ of CPT-11 $(100 \mu \mathrm{M})$ was then administered to three sites within the tumor using a 28-gauge needle, the animals were killed, and the tumor masses were harvested. mRNA expression, carboxylesterase activity, and intracellular concentration of CPT- 11 and SN-38 were determined in the tumor lysates as described above for the in vitro studies.

To determine if the combination of local administration of AdCMV.CE and local administration of CPT-11 could suppress the growth of tumors in vivo, A549 cells $\left(8 \times 10^{6}\right)$ were injected subcutaneously in the flanks of athymic Balb/c nu/nu mice. After $7 \mathrm{~d}$, randomized tumors of comparative size were administered AdCMV.CE $\left(10^{9} \mathrm{pfu}\right)$ or AdCMV.Null $\left(10^{9} \mathrm{pfu}\right)$ followed by CPT-11 (each $\left.n=9\right)$ or PBS $(n=8)$. The vectors or PBS were delivered intratumorally in a $100-\mu l$ volume on day 8 . After $24 \mathrm{~h}$, the animals received once daily intratumoral injections of $100 \mu \mathrm{l}$ of CPT-11 $(10 \mu \mathrm{g} / \mathrm{ml})$ or PBS until day 15. Using the same methods, suppressions of the tumor growth with the AdCMV.CE/CPT-11 and controls were evaluated using the H157 and HeLa cell lines as sources of the tumors. Tumor size was measured in a blinded fashion using calipers every $3 \mathrm{~d}$ up to day 34 . Tumor size was calculated using two dimensions as the product of width $\times$ length $(24)$.

To determine if there were adverse systemic effects from the AdCMV.CE/CPT-11 system, white blood cell counts, blood platelet counts, and body weight were compared in each group $15 \mathrm{~d}$ after tumor implantation.

\section{Results}

In vitro expression. In vitro evaluation of the AdCMV.CE vector demonstrated that it functioned to express the carboxylesterase cDNA at the mRNA and protein levels. Northern analysis revealed $1.7 \mathrm{~kb}$ mRNA transcripts of the carboxylesterase cDNA in A549 cells infected with AdCMV.CE, but not in cells infected with a control vector (Fig. 1). After AdCMV.CE infection of A549 cells, carboxylesterase activity increased with time, with a $>40$-fold increase by $72 \mathrm{~h}(P<$ 0.001 , all comparisons to a Null vector) (Fig. $2 A$ ). Analysis of the cell lysate for CPT-11 and SN-38 demonstrated that the CPT-11 was converted effectively to its active metabolite $\mathrm{SN}$ 38 in the A549 cells infected with AdCMV.CE, but not in A549 cells infected with AdCMV.Null (Fig. 2 B).

Cytotoxicity. Comparison of the sensitivities of the naive and vector-modified A549 cells demonstrated that infection 


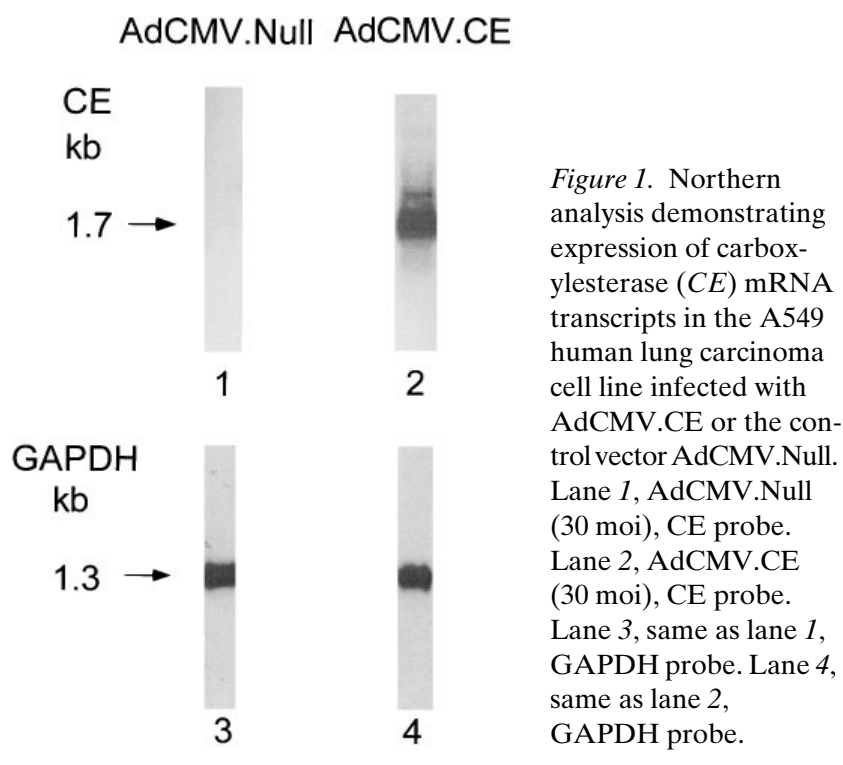

with AdCMV.CE shifted the sensitivity of the cells to lower levels of CPT-11 (Fig. $3 \mathrm{~A}$ ). In this regard, the $\mathrm{IC}_{50}$ value for CPT-11 of the A549 cells infected with AdCMV.Null was 18.5 $\mu \mathrm{g} / \mathrm{ml}$ and that of naive A549 cells was $17.0 \mu \mathrm{g} / \mathrm{ml}(P>0.05)$. In contrast, the $\mathrm{IC}_{50}$ value for CPT-11 of the A549 cells infected with AdCMV.CE was $1.1 \mu \mathrm{g} / \mathrm{ml}$ for $50 \mathrm{moi}, 2.0 \mu \mathrm{g} / \mathrm{ml}$ for $30 \mathrm{moi}$, and $2.5 \mu \mathrm{g} / \mathrm{ml}$ for $10 \mathrm{moi}(P<0.001$, all comparisons to controls). Thus infection with the AdCMV.CE vector shifted the sensitivity to CPT-11 7 to 17 -fold compared to that of naive or control virus infected cells, depending on the moi of the AdCMV.CE vector used to infect the cells. The change of the sensitivity of a total of 10 lung and nonlung cell lines were tested in a similar fashion. The $\Delta \mathrm{IC}_{50}$ values were different among the different cell lines $\left(\Delta \mathrm{IC}_{50} 1.2-7.5\right.$; Fig. $\left.3 \mathrm{~B}\right)$, but in all cases AdCMV.CE transfer of the carboxylesterase cDNA was associated with an increased sensitivity of the cell line to CPT-11. These data are consistent with the increased sensitivity to CPT-11 of a rhabdomyosarcoma cell line after stable transfection of a CE plasmid (25).

Bystander effect. To evaluate the bystander effect of the AdCMV.CE/CPT-11 strategy, A549 infected with AdCMV.CE or control virus were mixed in various percentages with uninfected cells in media containing CPT-11. The data demonstrated that after $72 \mathrm{~h}$, when only $10 \%$ of cells had been infected with AdCMV.CE, there was $48 \%$ of growth suppression $(P<0.05$, compared to AdCMV.Null control; Fig. $4 A)$. At higher proportion of AdCMV.CE-infected cells, there was a corresponding decreased proportion of cells surviving $(P<$ 0.001, all comparisions to AdCMV.Null controls). These data suggested that infection with AdCMV.CE plus the addition of CPT-11 to the culture medium effectively induced a cytotoxicity to a larger number of A549 cells than the portion of the cells actually infected with the AdCMV.CE vector. To explore the bystander effect further, serial dilutions of media obtained from A549 cells infected with AdCMV.CE and exposed to CPT-11 were added to naive A549 cells (Fig. 4 B). This resulted in a dose-dependent decrease in cell cytotoxicity with a dilution of the supernatant 1:10 or less $(P<0.05$, all comparisons to AdCMV.Null control).
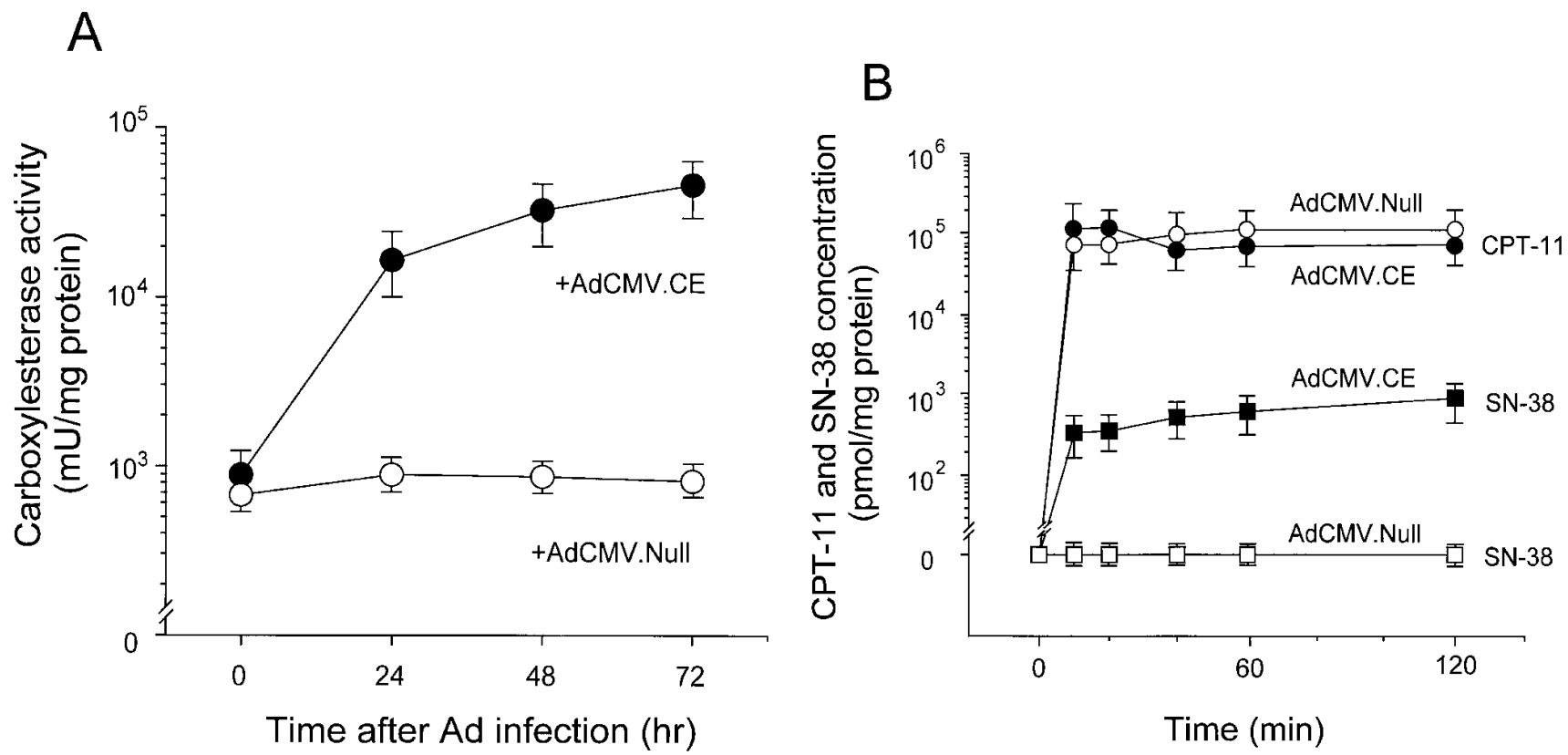

Figure 2. In vitro evaluation of AdCMV.CE-mediated expression of functional carboxylesterase (CE). (A) Time course of CE activity in A549 cells after infection with AdCMV.CE $(\bullet, 30$ moi) or AdCMV.Null $(\bigcirc, 30$ moi). (B) Time course of CPT-11 and SN-38 concentration in the A549 cells after infection with AdCMV.CE or AdCMV.Null (both 50 moi) and exposure to CPT-11. Shown are data for CPT-11 (+AdCMV.CE, 0; + AdCMV.Null, $\bigcirc)$ and SN-38 (+AdCMV.CE, $\mathbf{\square} ;+$ AdCMV.Null, $\square)$. Note that the CPT-11 levels in the lysates are similar with AdCMV.CE and AdCMV.Null infection, but that SN-38 is observed only with AdCMV.CE infection. For both panels, the results are presented as the mean \pm standard error of the mean of three experiments. 

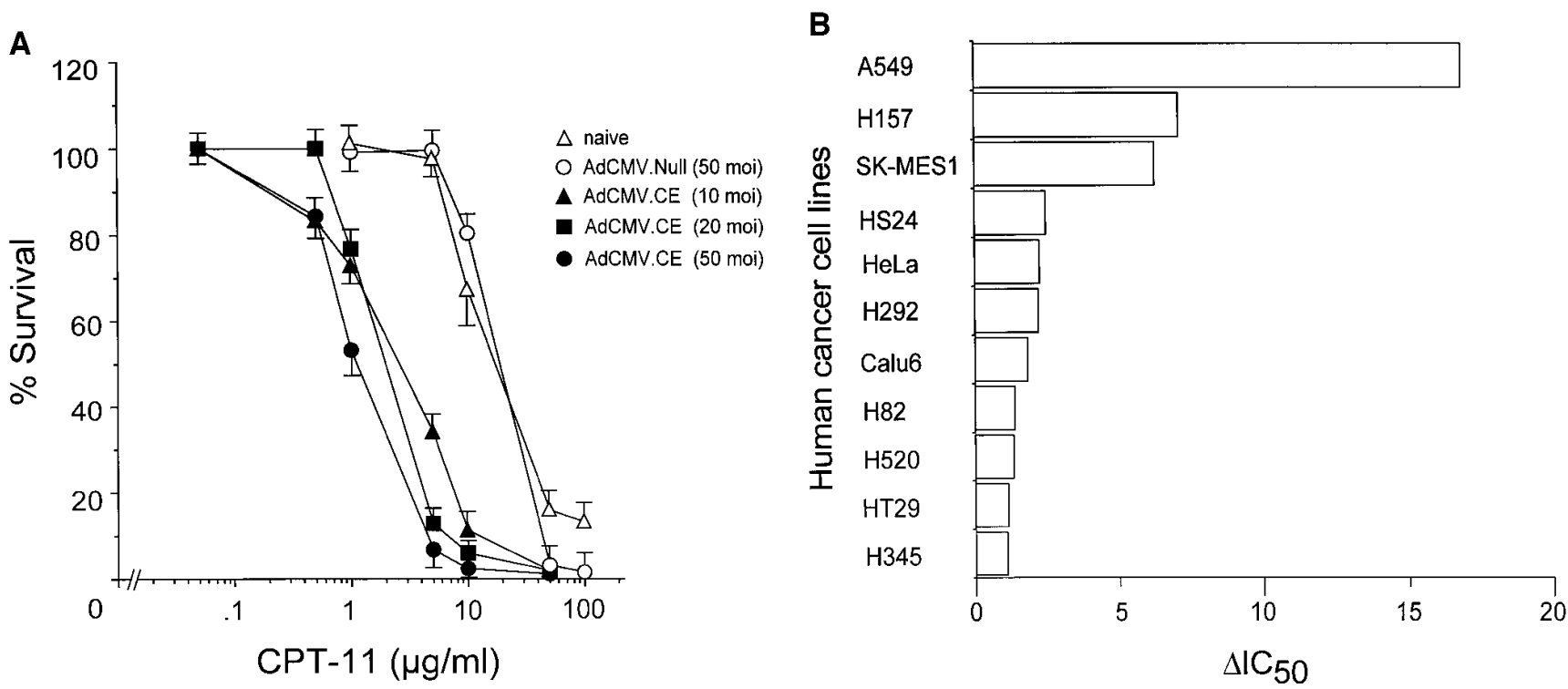

Figure 3. The effect of AdCMV.CE on the cytotoxic activity of CPT-11 in tumor cell lines in vitro. (A) A549 cells. After 72-h infection of AdCMV.CE, AdCMV.Null or no treatment (naive), the cells were exposed to various concentration of CPT-11 for an additional $72 \mathrm{~h}$. The viable cells number was assessed using MTT assay. Shown are data for AdCMV.CE (10 moi, $\mathbf{\Delta} ; 20$ moi, $\mathbf{\square} ; 50$ moi, ๑); AdCMV.Null (50 moi, O); and naive $(\triangle)$. The results are presented as the means \pm standard error of the mean of three experiments. $(B) \Delta \mathrm{IC}_{50}$ comparision in lung $(A 549, H 157$, SK-MES1, HS24, H292, Calu6, H82, H520, H345) and nonlung (HeLa and HT29) cell lines. See Methods for details.
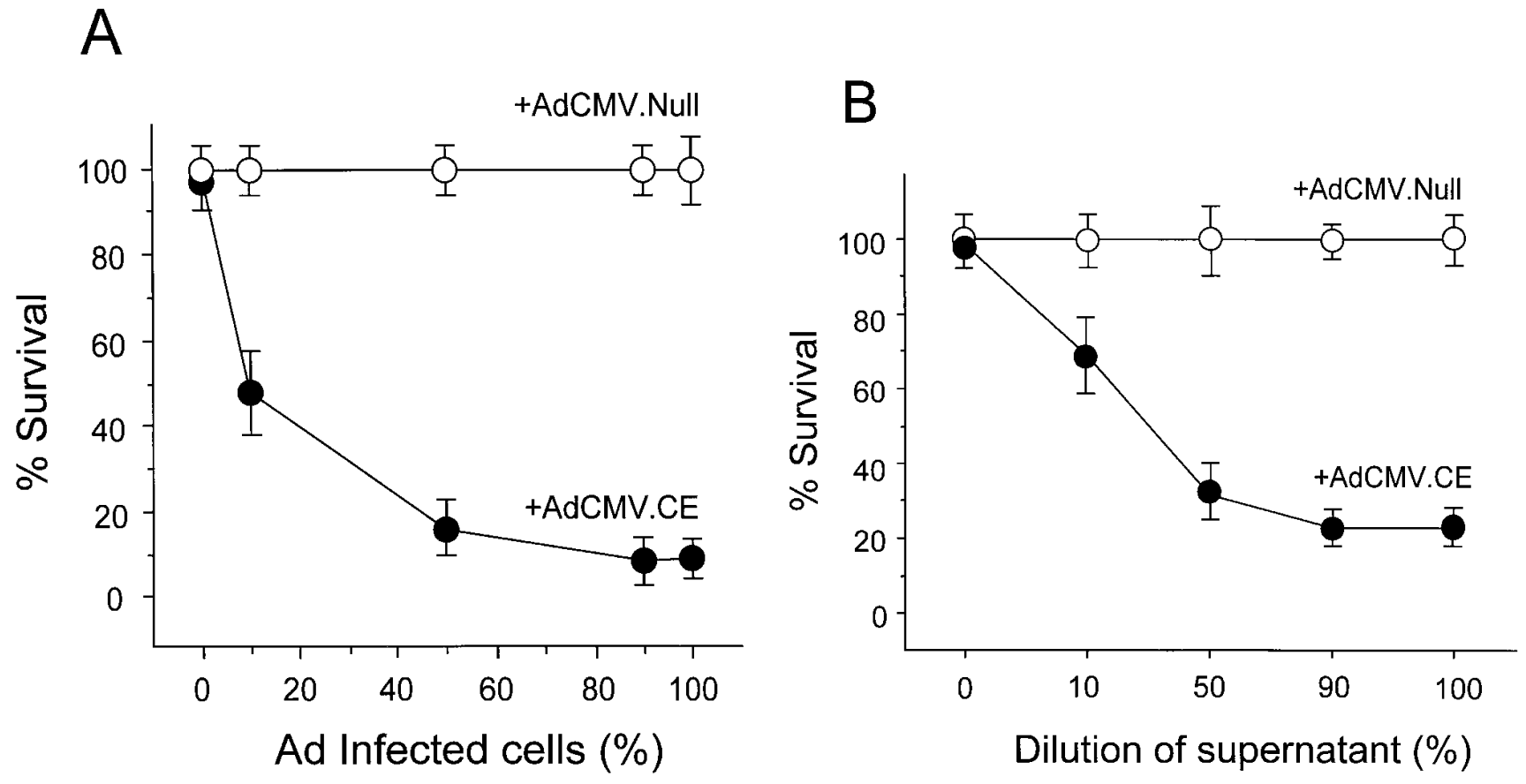

Figure 4. Bystander effect of AdCMV.CE plus CPT-11 on the cytotoxicity of A549 cells in vitro. (A) Bystander activity evaluated by mixing various proportions of AdCMV.CE-infected or AdCMV.Null-infected A549 cells with naive cells. A549 cells were infected with AdCMV.CE (50 moi), AdCMV.Null (50 moi), or no virus. After $24 \mathrm{~h}, 4 \times 10^{3}$ cells (total of infected and uninfected cells) were mixed in CPT-11 containing media $(10 \mu \mathrm{g} / \mathrm{ml})$ at various percentages of Ad-infected cells with naive cells $(0-100 \%)$. After $72 \mathrm{~h}$, viable cells number was assessed using the MTT assay. Shown are mixtures of AdCMV.CE-infected cells and naive cells $(\bullet)$ as well as mixtures of AdCMV.Null cells and naive cells $(O)$. $(B)$ Bystander activity evaluated in supernatant of A549 cells infected or not infected with AdCMV.CE or AdCMV.Null. A549 cells were infected with AdCMV.CE (50 moi), AdCMV.Null (50 moi), or no virus. After $24 \mathrm{~h}, \mathrm{CPT}-11$ was added $(10 \mu \mathrm{g} / \mathrm{ml})$. The supernatant was collected $24 \mathrm{~h}$ later, and added to uninfected A549 monolayers $\left(4 \times 10^{3}\right.$ cells/well) at various dilutions of the supernatant. Viable cell number was assessed at $72 \mathrm{~h}$ using the MTT assay. Shown are data relating the percentage survival relative to naive supernatant with supernatant of Ad-infected cells for AdCMV.CE $(\bullet)$ and AdCMV.Null $(\bigcirc)$. The results are expressed as the mean \pm standard error of the mean of three experiments. 

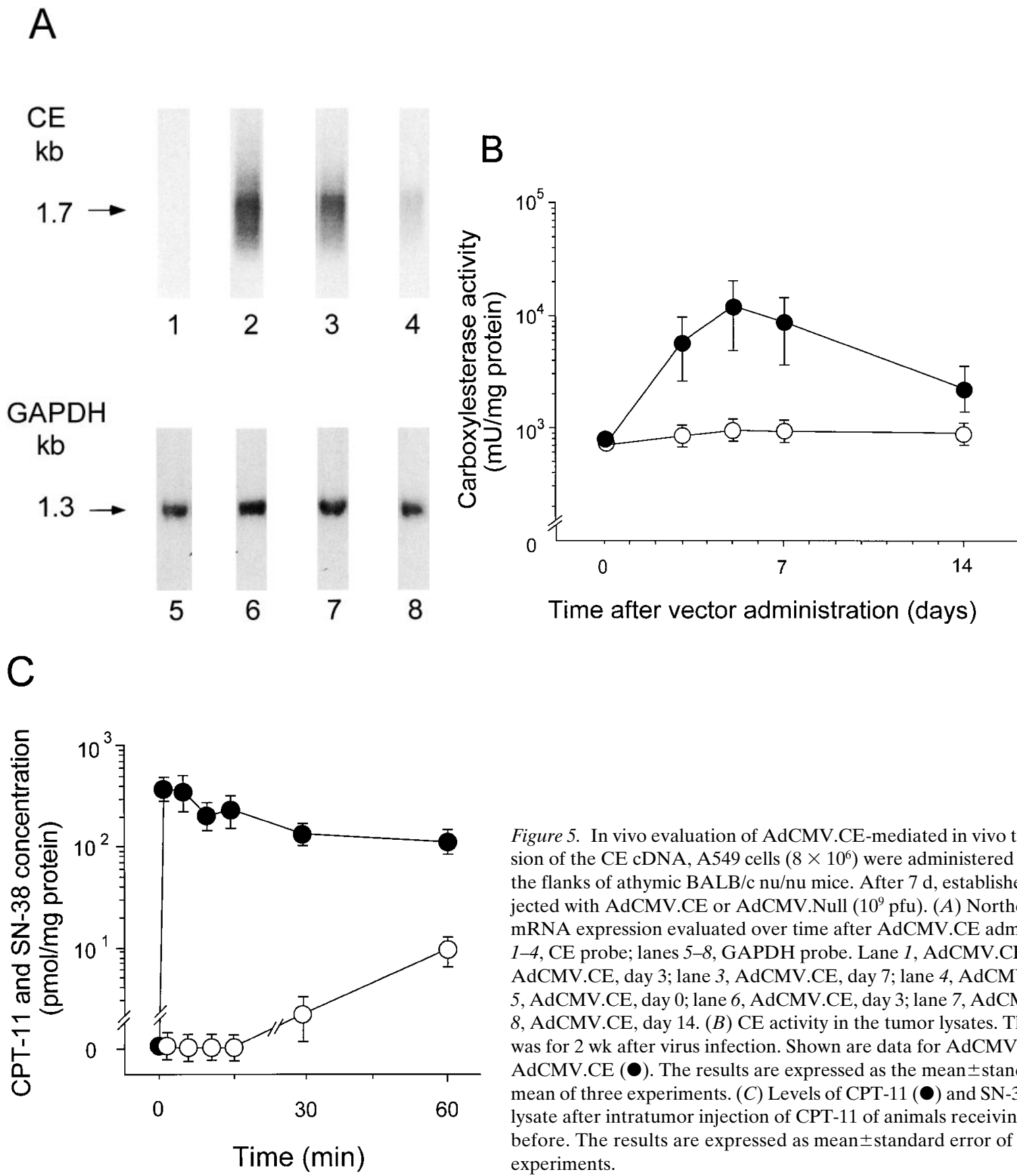

Figure 5. In vivo evaluation of AdCMV.CE-mediated in vivo transfer and expression of the CE cDNA, A549 cells $\left(8 \times 10^{6}\right)$ were administered subcutaneously in the flanks of athymic BALB/c nu/nu mice. After $7 \mathrm{~d}$, established tumors were injected with AdCMV.CE or AdCMV.Null $\left(10^{9} \mathrm{pfu}\right)$. $(A)$ Northern analysis of mRNA expression evaluated over time after AdCMV.CE administration. Lanes 1-4, CE probe; lanes 5-8, GAPDH probe. Lane 1, AdCMV.CE, day 0; lane 2, AdCMV.CE, day 3; lane 3, AdCMV.CE, day 7; lane 4, AdCMV.CE, day 14; lane 5, AdCMV.CE, day 0; lane 6, AdCMV.CE, day 3; lane 7, AdCMV.CE, day 7; lane 8, AdCMV.CE, day 14. (B) CE activity in the tumor lysates. The evaluation was for 2 wk after virus infection. Shown are data for AdCMV.Null $(\bigcirc)$ and AdCMV.CE (-). The results are expressed as the mean \pm standard error of the mean of three experiments. $(C)$ Levels of CPT-11 $(\bullet)$ and SN-38 $(O)$ in the tumor lysate after intratumor injection of CPT- 11 of animals receiving AdCMV.CE $5 \mathrm{~d}$ before. The results are expressed as mean \pm standard error of the mean of these experiments.

In vivo function of AdCMV.CE. AdCMV.CE infection of A549-derived subcutaneous tumors in vivo demonstrated that the human carboxylesterase gene could be expressed in cells comprising solid tumors with reasonable efficiency from a single injection. First, Northern analysis revealed 1.7-kb mRNA transcripts of the carboxylesterase cDNA in tumors infected with AdCMV.CE (Fig. $5 \mathrm{~A}$ ). Second, carboxylesterase activity was increased with time after the infection of AdCMV.CE to tumor, with levels peaking 12 -fold over baseline $3 \mathrm{~d}$ after infection, and continuing to be elevated for at least $2 \mathrm{wk}$, but not in tumors infected with control vector (Fig. 5 B). Third, in vivo administration of AdCMV.CE plus CPT-11 to the tumor demonstrated that the CPT-11 was converted effectively to active metabolite, $\mathrm{SN}-38$ in the tumor (Fig. 5 C).
Consistent with the in vitro and in vivo studies with AdCMV.CE and CPT-11, administration of AdCMV.CE to tumors of A549 cells in nude mice together with local administration of CPT-11 resulted in a suppression of tumor growth compared to that in the control groups (Fig. $6 \mathrm{~A}$ ). In this regard, tumors in control groups, treated with AdCMV.CE without CPT-11 administration, tumors treated with control virus together with CPT-11, and tumors injected with PBS alone all showed similar growth curves over the $34 \mathrm{~d}$ of evaluation $(P>$ 0.2 , all comparisions, all time points). In contrast, tumor injected with AdCMV.CE with CPT-11 administration resulted in suppression of tumor growth, with $35 \%$ reduction in growth compared to controls at day $27(P<0.01$, compared to all controls) and a $41 \%$ reduction in tumor growth at day $34(P<$ 

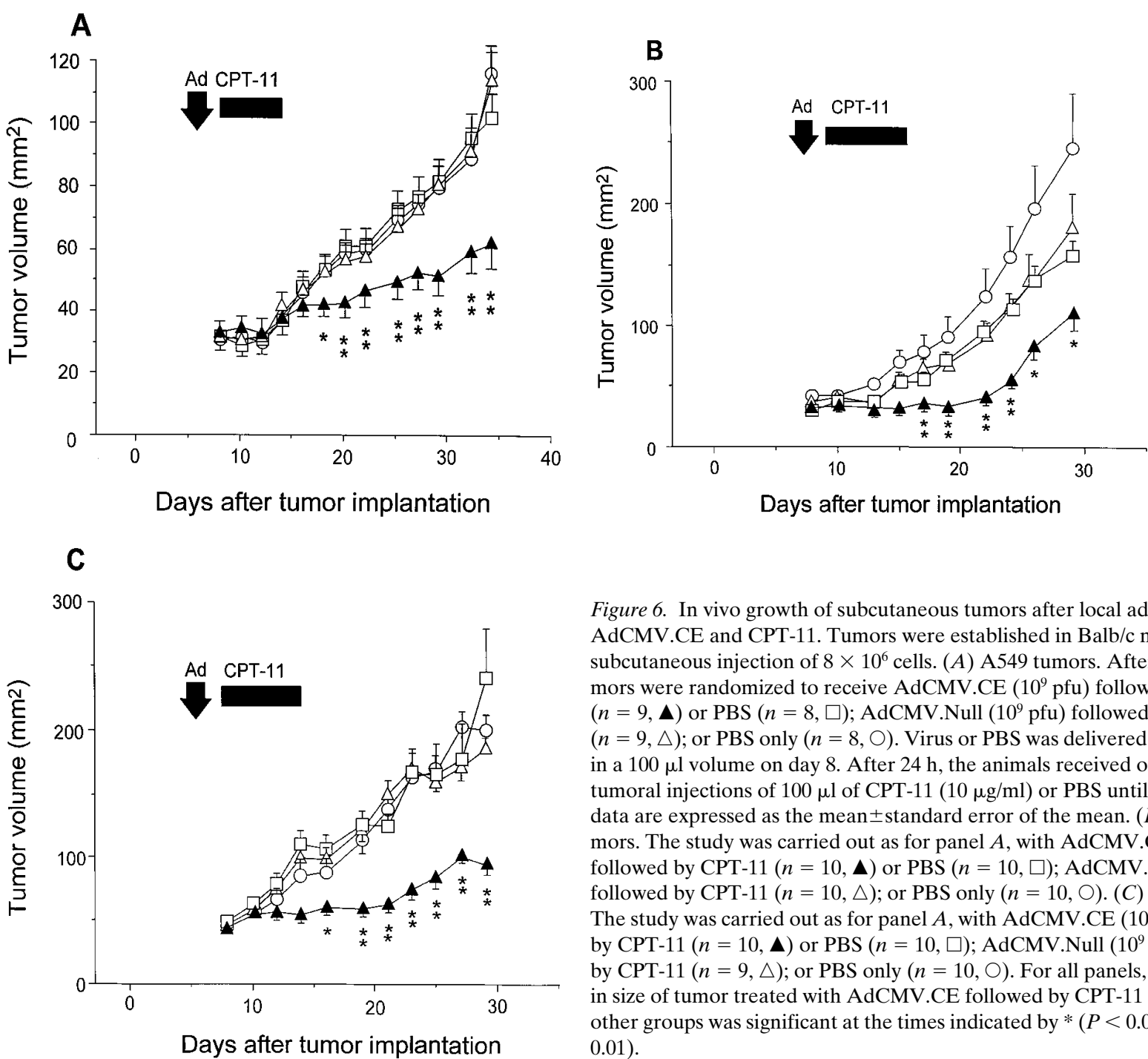

Figure 6. In vivo growth of subcutaneous tumors after local administration of AdCMV.CE and CPT-11. Tumors were established in Balb/c nu/nu mice by subcutaneous injection of $8 \times 10^{6}$ cells. (A) A549 tumors. After $7 \mathrm{~d}$, the tumors were randomized to receive AdCMV.CE ( $\left.10^{9} \mathrm{pfu}\right)$ followed by CPT-11 $(n=9, \mathbf{\Delta})$ or PBS $(n=8, \square)$; AdCMV.Null $\left(10^{9} \mathrm{pfu}\right)$ followed by CPT-11 $(n=9, \triangle)$; or PBS only $(n=8, \bigcirc)$. Virus or PBS was delivered intratumorally in a $100 \mu \mathrm{l}$ volume on day 8 . After $24 \mathrm{~h}$, the animals received once daily intratumoral injections of $100 \mu \mathrm{l}$ of CPT-11 $(10 \mu \mathrm{g} / \mathrm{ml})$ or PBS until day 15 . The data are expressed as the mean \pm standard error of the mean. (B) H157 tumors. The study was carried out as for panel $A$, with AdCMV.CE $\left(10^{9} \mathrm{pfu}\right)$ followed by CPT-11 $(n=10, \mathbf{\Delta})$ or PBS $(n=10, \square)$; AdCMV.Null $\left(10^{9} \mathrm{pfu}\right)$ followed by CPT-11 $(n=10, \triangle)$; or PBS only $(n=10, \bigcirc)$. $(C)$ HeLa tumors. The study was carried out as for panel $A$, with AdCMV.CE $\left(10^{9} \mathrm{pfu}\right)$ followed by CPT-11 $(n=10, \mathbf{\Delta})$ or PBS $(n=10, \square)$; AdCMV.Null $\left(10^{9} \mathrm{pfu}\right)$ followed by CPT-11 $(n=9, \triangle)$; or PBS only $(n=10, \bigcirc)$. For all panels, the difference in size of tumor treated with AdCMV.CE followed by CPT-11 compared with other groups was significant at the times indicated by * $(P<0.05)$ and ** $(P<$ $0.01)$.

0.01 , compared to all controls) following virus delivery. Significant reductions of tumor growth were also observed in H157 and HeLa tumor (Fig. 6, $B$ and $C$ ). No associated systemic toxicity (reflected as white blood cell count, platelets, body weight, and animal deaths) was seen from adenovirus infection nor from CPT-11 administration (Table I). In addition, there

Table I. Assessment of Systemic Toxicity*

\begin{tabular}{lccc}
\hline \multicolumn{1}{c}{ Treatment } & White blood count & Platelets & Body weight \\
\hline & $/ \mathrm{mm}^{3}$ & $\times 10^{4} / \mathrm{mm}^{3}$ & grams \\
& $4998 \pm 593$ & $73 \pm 9$ & $15.0 \pm 0.9$ \\
PBS only & $5438 \pm 561$ & $74 \pm 15$ & $15.7 \pm 0.5$ \\
PBS + CPT-11 & $7780 \pm 1523$ & $79 \pm 10$ & $14.2 \pm 0.4$ \\
AdCMV.CE + PBS & $5587 \pm 471^{\S}$ & $90 \pm 15^{\S}$ & $14.7 \pm 0.4^{\S}$ \\
AdCMV.CE + CPT-11 & & & \\
\end{tabular}

*Data are for animals with A549 tumors; the data are presented as mean \pm standard error of the mean. No deaths were observed in any group. ${ }^{\ddagger}$ The $P$ values compare the AdCMV.CE + CPT- 11 group to each of the other groups. ${ }^{\S} P>0.05$. are no differences between the groups in general alertness, the state of the skin coat, and food intake.

\section{Discussion}

Carboxylesterases (CE), 60-kD proteins of the serine esterase family, are widely distributed in different tissues with the highest activity found in hepatic microsomal fractions $(13,26)$. The hydrolysis of carboxyl ester, amide, and thioester bonds in a variety of drugs and environmental chemicals by carboxylesterase is generally considered a housekeeping detoxification reaction, resulting in loss of biological activity of the drug/ chemical $(13,26,27)$. The present study capitalizes on the metabolic function of human carboxylesterase to convert the drug CPT-11 to its more active metabolite SN-38 as a gene therapy prodrug transfer strategy to inhibit tumor growth in vivo. Using a replication-deficient, recombinant adenovirus to transfer the human CE cDNA to tumor masses of human A549 lung carcinoma cells growing in the flanks of nude mice resulted in expression of the CE enzyme within the target tumor. The data also demonstrate that concomitant local administration of prodrug CPT-11 results in the conversion of CPT-11 to the ac- 
tive metabolite SN-38 in the local milieu, thus effectively suppressing local tumor growth without systemic toxicity.

Chemotherapy with CPT-11. CPT-11 demonstrates significant antitumor activities against a broad spectrum of experimental tumors $(6-9,28)$. Based on animal and human studies, CPT-11 is now available in Japan for the treatement of lung, cervical, and ovarian cancer $(1,2,5)$, and in France and the US for colorectal cancer $(29,30)$. CPT-11 is a promising anticancer agent with a unique mechanism of action, the inhibition of the DNA unwinding enzyme, topoisomerase I (6). The major problem with CPT-11 and the camptothecins in general as chemotherapeutic agents is the systemic toxicity associated with their use, particularly with granulocytopenia and diarrhea contributing to dose-limiting toxicity $(10,11)$. Camptothecins can also damage DNA, thus evoking the specter of increased risk for malignancy associated with their use (31). In a tumor growth model, we showed the suppression of the tumor growth using the only total of $7 \mu \mathrm{g}$ of CPT-11 for local injection, a dose $<1 \%$ of the intraperitoneal or intravenous systemic doses of CPT-11 required for suppression of experimental tumors in mice (6).

Prodrug gene therapy with AdCMV.CE. All prodrug strategies of gene therapy are based on the theoretical concept that the systemic toxicity associated with chemotherapeutic agents might be minimized by transferring to the tumor, or surrounding tissues, an enzyme capable of converting an administrated prodrug to a toxic chemotherapeutic agent, thus achieving high concentrations of the toxic product only in the milieu of the tumor $(32,33)$. Examples of this strategy include transfer of the herpes simplex thymidine kinase (hstk) gene to convert gancyclovir to active agents to suppress growth of glioma, mesothelioma, lung, hepatocellular carcinoma, pancreatic cancer, gastric cancer, and breast cancer (34-40); cytosine deaminase to convert 5-FC to 5-FU for the treatment of colorectal cancer $(17,24,41-43)$; deoxycytidine kinase to convert ara-C to araCMP for the treatment of glioma (44); nitroreductase to activate CB1954 for colorectal cancer (45); and carboxypeptidase G2 to activate 4-[(2-chloroethyl) (2-mesyloxyethyl) amino] benzoyl-L-glutamic acid (CMDA) for ovarian cancer (46). The present study demonstrates that by using an Ad vector to transfer the CE cDNA, CPT-11, a water-soluble camptothecin analogue, was incorporated after the injection to the tumor and converted to $\mathrm{SN}-38$, with consequent antitumor effects.

One theoretical advantage of the AdCMV.CE/CPT-11 strategy is a bystander effect, where the active chemotherapeutic agent diffuses from the tumor cell in which it was produced to neighboring malignant cells in sufficient concentrations to suppress growth. In this regard, infection with AdCMV.CE and the addition of CPT-11 shifts the sensitivity of tumor cells in vitro to allow toxicity at seven to 17-fold lower doses of CPT-11, with as few as $10 \%$ of A549 cells infected with AdCMV.CE to result in cytotoxicity of as much as $48 \%$ of the total population of tumor cells. In the context that in vivo infection with gene transfer vectors have a limited effectiveness in the proportion of the total tumor cells that are infected $(24,41)$, the current study serves as a paradigm for local adjuvant therapy for solid tumors, such as the treatment of intrabronchial tumors, lung tumor invading into the chest wall, and inoperable intrapulmonary tumors. In this context, the AdCMV.CE/CPT-11 system has a number of potential advantages for cancer gene therapy. First, the total dose of CPT-11 that could suppress the AdCMV.CE-infected tumor is well be- low the systemic administration dose, thus theoretically reducing the toxicity associated with the use of systemic CPT-11. Second, as opposed to herpes simplex thymidine kinase and other currently utilized chemosensitization genes, such as cytosine deaminase, $\mathrm{CE}$ is a human gene and thus will not likely be associated with significant anti-CE immunologic response in humans. Finally, although in vivo gene transfer vector systems continue to improve in efficiency, no currently available in vivo gene transfer vectors are capable of transferring a gene to all metastatic tumor cells. In this regard, the bystander effect demonstrated by AdCMV.CE/CPT-11 in combination with tissue-specific promoters could, theoretically, be useful for systemic control of advanced cancer.

\section{Acknowledgments}

We would like to thank M. Suzuki, K. Narumi, T. Fushimi, A. Koller, and P. Leopold in our laboratory; and N. Mohamed for help in preparation of the manuscript.

These studies were supported, in part, by National Institutes of Health R01 CA75192, the Will Rogers Memorial Fund, Los Angeles, $\mathrm{CA}$, and GenVec, Inc., Rockville, MD.

\section{References}

1. Fukuoka, M., H. Niitani, A. Suzuki, M. Motomiya, K. Hasegawa, Y. Nishiwaki, T. Kuriyama, Y. Ariyoshi, S. Negoro, N. Masuda, et al. 1992. A phase II study of CPT-11, a new derivative of camptothecin, for previously untreated non-small-cell lung cancer. J. Clin. Oncol. 10:16-20.

2. Masuda, N., M. Fukuoka, Y. Kusunoki, K. Matsui, N. Takifuji, S. Kudoh, S. Negoro, M. Nishioka, K. Nakagawa, and M. Takada. 1992. CPT-11: a new derivative of camptothecin for the treatment of refractory or relapsed small-cell lung cancer. J. Clin. Oncol. 10:1225-1229.

3. Ohno, R., K. Okada, T. Masaoka, A. Kuramoto, T. Arima, Y. Yoshida, H. Ariyoshi, M. Ichimaru, Y. Sakai, M. Oguro, et al. 1990. An early phase II study of CPT-11: a new derivative of camptothecin, for the treatment of leukemia and lymphoma. J. Clin. Oncol. 8:1907-1912.

4. Shimada, Y., M. Yoshino, A. Wakui, I. Nakao, K. Futatsuki, Y. Sakata, M. Kambe, T. Taguchi, N. Ogawa, and The CPT-11 Gastrointestinal Cancer Study Group. 1993. Phase II study of CPT-11, a new camptothecin derivative, in metastatic colorectal cancer. J. Clin. Oncol. 11:909-913.

5. Takeuchi, S., H. Takamizawa, Y. Takeda, T. Ohkawa, T. Tamaya, K. Noda, T. Sugawa, K. Sekiba, M. Yakushiji, and T. Taguchi. 1991. An early phase II study of CPT-11 in gynecologic cancers. Research group of CPT-11 in gynecologic cancers. Gan. To. Kagaku. Ryoho. 18:579-584.

6. Kunimoto, T., K. Nitta, T. Tanaka, N. Uehara, H. Baba, M. Takeuchi, T. Yokokura, S. Sawada, T. Miyasaka, and M. Mutai. 1987. Antitumor activity of 7-ethyl-10-[4-(1-piperidino)-1-piperidino]carbonyloxy-camptothecin, a novel water-soluble derivative of camptothecin, against murine tumors. Cancer Res. 47:5944-5947.

7. Kawato, Y., M. Aonuma, Y. Hirota, H. Kuga, and K. Sato. 1991. Intracellular roles of SN-38, a metabolite of the camptothecin derivative CPT-11, in the antitumor effect of CPT-11. Cancer Res. 51:4187-4191.

8. Kaneda, N., H. Nagata, T. Furuta, and T. Yokokura. 1990. Metabolism and pharmacokinetics of the camptothecin analogue CPT-11 in the mouse. Cancer Res. 50:1715-1720.

9. Lavelle, F., M.C. Bissery, S. Andre, F. Roquet, and J.F. Riou. 1996. Preclinical evaluation of CPT-11 and its active metabolite SN-38. Semin. Oncol. 23: $11-20$.

10. Negoro, S., M. Fukuoka, N. Masuda, M. Takada, Y. Kusunoki, K. Matsui, N. Takifuji, S. Kudoh, H. Niitani, and T. Taguchi. 1991. Phase I study of weekly intravenous infusions of CPT-11, a new derivative of camptothecin, in the treatment of advanced non-small-cell lung cancer. J. Natl. Cancer. Inst. 83: 1164-1168.

11. Ohe, Y., Y. Sasaki, T. Shinkai, K. Eguchi, T. Tamura, A. Kojima, H Kunikane, H. Okamoto, A. Karato, H. Ohmatsu, et al. 1992. Phase I study and pharmacokinetics of CPT-11 with 5-day continuous infusion. J. Natl. Cancer. Inst. 84:972-974.

12. Hersh, J., R.G. Crystal, and B. Bewig. 1995. Modulation of gene expression after replication-deficient, recombinant adenovirus-mediated gene transfer by the product of a second adenovirus vector. Gene Ther. 2:124-131.

13. Kroetz, D.L., O.W. McBride, and F.J. Gonzalez. 1993. Glycosylationdependent activity of baculovirus-expressed human liver carboxylesterases: cDNA cloning and characterization of two highly similar enzyme forms. Biochemistry. 32:11606-11617. 
14. Korst, R.J., B. Bewig, and R.G. Crystal. 1995. In vitro and in vivo transfer and expression of human surfactant SP-A- and SP-B-associated protein cDNAs mediated by replication-deficient, recombinant adenoviral vectors. Hum. Gene Ther. 6:277-287.

15. McGrory, W.J., D.S. Bautista, and F.L. Graham. 1988. A simple technique for the rescue of early region I mutations into infectious human adenovirus type 5. Virology. 163:614-617.

16. Ohwada, A., S. Rafii, M.A. Moore, and R.G. Crystal. 1996. In vivo adenovirus vector-mediated transfer of the human thrombopoietin cDNA maintains platelet levels during radiation- and chemotherapy-induced bone marrow suppression. Blood. 88:778-784.

17. Ohwada, A., E.A. Hirschowitz, and R.G. Crystal. 1996. Regional delivery of an adenovirus vector containing the Escherichia coli cytosine deaminase gene to provide local activation of 5-fluorocytosine to suppress the growth of colon carcinoma metastatic to liver. Hum. Gene Ther. 7:1567-1576.

18. Rosenfeld, M.A., K. Yoshimura, B.C. Trapnell, K. Yoneyama, E.R. Rosenthal, W. Dalemans, M. Fukayama, J. Bargon, L.E. Stier, L. Stratford-Perricaudet, et al. 1992. In vivo transfer of the human cystic fibrosis transmembrane conductance regulator gene to the airway epithelium. Cell. 68:143-155.

19. Thomas, P.S. 1980. Hybridization of denatured RNA and small DNA fragments transferred to nitrocellulose. Proc. Natl. Acad. Sci. USA. 77:52015205 .

20. Mertz, L.M., and A. Rashtchian. 1994. Nucleotide imbalance and polymerase chain reaction: effects on DNA amplification and synthesis of high specific activity radiolabeled DNA probes. Anal. Biochem. 221:160-165.

21. Krisch, K. 1966. Reaction of a microsomal esterase from hog-liver with diethyl p-nitrophenyl phosphate. Biochim. Biophys. Acta. 122:265-280.

22. Barilero, I., D. Gandia, J.P. Armand, A. Mathieu-Boue, M. Re, A. Gouyette, and G.G. Chabot. 1992. Simultaneous determination of the camptothecin analogue CPT-11 and its active metabolite SN-38 by high-performance liquid chromatography: application to plasma pharmacokinetic studies in cancer patients. J. Chromatogr. 575:275-280.

23. Mosmann, T. 1983. Rapid colorimetric assay for cellular growth and survival: application to proliferation and cytotoxicity assays. J. Immunol. Methods. 65:55-63.

24. Hirschowitz, E.A., A. Ohwada, W.R. Pascal, T.J. Russi, and R.G. Crystal. 1995. In vivo adenovirus-mediated gene transfer of the Escherichia coli cytosine deaminase gene to human colon carcinoma-derived tumors induces chemosensitivity to 5-fluorocytosine. Hum. Gene Ther. 6:1055-1063.

25. Danks, M.K., C.L. Morton, C.A. Pawlik, and P.M. Potter. 1998. Overexpression of a rabbit liver carboxylesterase sensitizes human tumor cells to CPT11. Cancer Res. 58:20-22.

26. Munger, J.S., G.P. Shi, E.A. Mark, D.T. Chin, C. Gerard, and H.A. Chapman. 1991. A serine esterase released by human alveolar macrophages is closely related to liver microsomal carboxylesterases. J. Biol. Chem. 266:1883218838

27. Shibata, F., Y. Takagi, M. Kitajima, T. Kuroda, and T. Omura. 1993. Molecular cloning and characterization of a human carboxylesterase gene. Genomics. 17:76-82.

28. Tsuruo, T., T. Matsuzaki, M. Matsushita, H. Saito, and T. Yokokura. 1988. Antitumor effect of CPT-11, a new derivative of camptothecin, against pleiotropic drug-resistant tumors in vitro and in vivo. Cancer Chemother. Pharmacol. 21:71-74

29. Armand, J.P., M. Ducreux, M. Mahjoubi, D. Abigerges, R. Bugat, G. Chabot, P. Herait, M. de Forni, and P. Rougier. 1995. CPT-11 (irinotecan) in the treatment of colorectal cancer. Eur. J. Cancer. 31A:1283-1287.

30. Rothenberg, M.L., J.R. Eckardt, J.G. Kuhn, H.A. Burris III, J. Nelson, S.G. Hilsenbeck, G.I. Rodriguez, A.M. Thurman, L.S. Smith, S.G. Eckhardt, et al. 1996. Phase II trial of irinotecan in patients with progressive or rapidly recur- rent colorectal cancer. J. Clin. Oncol. 14:1128-1135.

31. Kojima, A., T. Shinkai, and N. Saijo. 1993. Cytogenetic effects of CPT11 and its active metabolite, SN-38 on human lymphocytes. Jpn. J. Clin. Oncol. 23:116-122.

32. Gutierrez, A.A., N.R. Lemoine, and K. Sikora. 1992. Gene therapy for cancer. Lancet. 339:715-721.

33. Moolten, F.L. 1994. Drug sensitivity ("suicide") genes for selective cancer chemotherapy. Cancer Gene Ther. 1:279-287.

34. Chen, S.H., H.D. Shine, J.C. Goodman, R.G. Grossman, and S.L.C. Woo. 1994. Gene therapy for brain tumors: regression of experimental gliomas by adenovirus-mediated gene transfer in vivo. Proc. Natl. Acad. Sci. USA. 91 3054-3057.

35. Culver, K.W., Z. Ram, S. Wallbridge, H. Ishii, E.H. Oldfield, and R.M. Blaese. 1992. In vivo gene transfer with retroviral vector-producer cells for treatment of experimental brain tumors. Science. 256:1550-1552.

36. Di Maio, J.M., B.M. Clary, D.F. Via, E. Coveney, T.N. Pappas, and H.K. Lyerly. 1994. Directed enzyme pro-drug gene therapy for pancreatic cancer in vivo. Surgery. 116:205-213.

37. Kaneko, S., P. Hallenbeck, T. Kotani, H. Nakabayashi, G. McGarrity, T. Tamaoki, W.F. Anderson, and Y.L. Chiang. 1995. Adenovirus-mediated gene therapy of hepatocellular carcinoma using cancer-specific gene expression. Cancer Res. 55:5283-5287.

38. Link, C.J., Jr., E.M. Kolb, and R.R. Muldoon. 1995. Preliminary in vitro efficacy and toxicities studies of the herpes simplex thymidine kinase gene system for the treatment of breast cancer. Hybridoma. 14:143-147.

39. Smythe, W.R., H.C. Hwang, K.M. Amin, S.L. Eck, B.L. Davidson, J.M. Wilson, L.R. Kaiser, and S.M. Albelda. 1994. Use of recombinant adenovirus to transfer the herpes simplex virus thymidine kinase (HSVtk) gene to thoracic neoplasms: an effective in vitro drug sensitization system. Cancer Res. 54:20552059.

40. Tanaka, T., F. Kanai, S. Okabe, Y. Yoshida, H. Wakimoto, H. Hamada, Y. Shiratori, K. Lan, M. Ishitobi, and M. Omata. 1996. Adenovirus-mediated prodrug gene therapy for carcinoembryonic antigen-producing human gastric carcinoma cells in vitro. Cancer Res. 56:1341-1345.

41. Huber, B.E., E.A. Austin, C.A. Richards, S.T. Davis, and S.S. Good. 1994. Metabolism of 5-fluorocytosine to 5-fluorouracil in human colorectal tumor cells transduced with the cytosine deaminase gene: significant antitumor effects when only a small percentage of tumor cells express cytosine deaminase. Proc. Natl. Acad. Sci. USA. 91:8302-8306.

42. Mullen, C.A., M.M. Coale, R. Lowe, and R.M. Blaese. 1994. Tumors expressing the cytosine deaminase suicide gene can be eliminated in vivo with 5 -fluorocytosine and induce protective immunity to wild type tumor. Cancer Res. 54:1503-1506.

43. Mullen, C.A., M. Kilstrup, and R.M. Blaese. 1992. Transfer of the bacterial gene for cytosine deaminase to mammalian cells confers lethal sensitivity to 5-fluorocytosine: a negative selection system. Proc. Natl. Acad. Sci. USA. 89:33-37.

44. Manome, Y., P.Y. Wen, Y. Dong, T. Tanaka, B.S. Mitchell, D.W. Kufe, and H.A. Fine. 1996. Viral vector transduction of the human deoxycytidine kinase cDNA sensitizes glioma cells to the cytotoxic effects of cytosine arabinoside in vitro and in vivo. Nat. Med. 2:567-573.

45. Green, N.K., D.J. Youngs, J.P. Neoptolemos, F. Friedlos, R.J. Knox C.J. Springer, G.M. Anlezark, N.P. Michael, R.G. Melton, M.J. Ford, et al. 1997. Sensitization of colorectal and pancreatic cancer cell lines to the prodrug 5-(aziridin-1-yl)-2,4-dinitrobenzamide (CB1954) by retroviral transduction and expression of the E. coli nitroreductase gene. Cancer Gene Ther. 4:229-238.

46. Marais, R., R.A. Spooner, Y. Light, J. Martin, and C.J. Springer. 1996. Gene-directed enzyme prodrug therapy with a mustard prodrug/carboxypeptidase G2 combination. Cancer Res. 56:4735-4742. 